\title{
ANALISIS PENGARUH KUALITAS MAKANAN DAN KUALITAS PELAYANAN TERHADAP KEPUASAN PELANGGAN DAN DAMPAKNYA PADA BEHAVIORAL INTENTION RESTORAN TOP YAMMIE
}

\author{
Priska Liliani \\ PT. Wita Tour \\ priscaaliliani19@gmail.com
}

\begin{abstract}
The purpose of this research is to analyze the effect of food quality, service quality on customer satisfaction and its impact on Top Yammie's restaurant behavioral intention. The analytical method used by the authors in conducting this research is to use quantitative research with a total sample of 100 people who are respondents who are people who eat at Top Yammie restaurants. In carrying out the data collection is done by distributing questionnaires in which there are several items of statement. in this study the variables are divided into several parts including food quality $\left(X_{1}\right)$, service quality $\left(X_{2}\right)$ to customer satisfaction $(Y)$, and behavioral intention $(Z)$. To measure the amount of influence on these variables, the authors use the path analysis method (path analysis). From the results of the analysis it was found that there was a significant influence both partially and simultaneously on food quality variables, service quality on customer satisfaction and its impact on Top Yammie's restaurant behavioral intentions.
\end{abstract}

Keywords: Food Quality, Service Quality, Customer Satisfaction, Behavioral Intention

\section{PENDAHULUAN}

Di jaman yang telah berkembang ini banyak para pengusaha restoran yang menciptakan makanan baru agar dapat bersaing dengan pasar. Dalam melakukan persaingan tersebut tentunya diperlukan strategi pemasaran yang baik bagi para pelaku usaha restoran, dikarenakan setiap hari selalu ada kompetitor baru sehingga jika restoran atau rumah makan yang sudah berdiri lama tidak dapat berinovasi dengan hal baru maka usaha restoran tersebut tidak akan di minati lagi oleh konsumen karena konsumen selalu mencari sesuatu yang unik dan baru. Restoran juga bisa berinovasi dalam hal menu makanan karena menu makanan yang enak dapat mempertahankan konsumen lama sekaligus mendatangkan konsumen baru. Tidak hanya dalam soal menu makanan akan tetapi konsep restoran juga perlu dipertimbangkan karena suasana restoran yang nyaman dapat membuat konsumen tertarik untuk datang kembali. Restoran merupakan sebuah tempat untuk menyantap makanan bersama keluarga di tempat 
pusat keramaian. Restoran pun kini tidak hanya sebuah tempat makan, tapi juga menjadi sebuah bagian gaya hidup bagi pecinta masakan kuliner. Restoran pun dalam menjual makanan tidak hanya mengandalkan rasa, tetapi juga desain itu sendiri sedemikian nyaman dan menarik dari segi tempat juga masakannya. Saat ini makanan merupakan salah satu kebutuhan pokok bagi masyarakat khususnya di daerah perkotaan. Di tengah kesibukan masyarakat perkotaan sehari-hari, sangat sulit rasanya untuk makan bersama dengan keluarga karena hal ini disibukan dengan berbagai aktifitas yang mereka tekuni. Oleh karena itu, ada banyak keluarga yang meluangkan waktu saat hari libur atau weekend untuk keluar rumah dan makan bersama di restoran, sehingga restoran keluarga sampai saat ini masih memiliki prospek yang masih menjanjikan. Dalam memilih restoran keluarga tentunya ada beberapa faktor yang harus dipertimbangkan untuk memilih restoran keluarga seperti banyaknya ragam menu makanan serta suasana yang nyaman sehingga cocok untuk family time. Di Indonesia pun ada juga restoran yang mengandalkan keunikan makanan dari negeri lain, seperti restoran Jepang dan Chinese yang akhir-akhir ini banyak diminati semua kalangan terutama kalangan muda. Masakan yang mengutamakan keindahan penyajian dan tidak melupakan nilai gizi ini mampu menarik calon pelaggan untuk mencobanya. Restoran Top Yammie merupakan sebuah restoran keluarga yang berada di Jakarta Barat khususnya terletak di Jalan Labu no.5, Mangga Besar, Taman Sari, Jakarta Barat, Daerah Khusus Ibu Kota Jakarta, Indonesia. yang merupakan merek dagang dari PT Fajar Group. Restoran ini sudah berdiri sejak tahun 1994, dengan menghidangkan makanan Chinesse Food dan Japanesse Food. Restoran Top Yammie memiliki menu andalan chinese food antara lain mulai dari Dimsum hongkong, Pocai with garlic, Garlic frog hotplate, Hainam rice, Salt-chicken half, Roasted pork spesial, Yamien Special. Sedangkan untuk menu andalan makanan Japanese food restoran Top Yammie antara lain Udon dan Ramen, dan masih banyak lagi menu yang di tawarkan. Restoran Top Yammie dalam menjalankan aktivitas bisnisnya beroperasi setiap hari dari pukul 08.00 sampai pukul 00.00 WIB, selain menyediakan 
masakan chinese food and Japanese food restoran tersebut terdapat ruang karoke dan fasilitas VIP room untuk keluarga yang ingin berkumpul secara lebih pribadi. Menurut manajer restoran Top Yammie, Bapak Pausian menjelaskan bahwa permasalahan yang terjadi saat ini minat pelanggan untuk terus datang ke restoran Top Yammie sangatlah sedikit. Selain itu dari tahun 2013 hingga tahun 2016, restoran Top Yammie mengalami penurunan pengunjung konsumen secara terus menerus. Berikut ini hasil data jumlah pengunjung konsumen restoran Top Yammie:

Tabel 1 Jumlah Pengunjung Konsumen Top Yammie Tahun 2013-2016

\begin{tabular}{cc} 
Tahun & Total Pengunjung \\
\hline 2013 & 77,347 \\
2014 & 72,037 \\
2015 & 67,321 \\
2016 & 60,250 \\
\hline Sumber: Restoran Top Yammie (2013-2016)
\end{tabular}

Berdasarkan pada tabel tersebut menunjukan bahwa restoran Top Yammie pada tahun 2013 hingga 2016 mengalami penurunan jumlah pengunjung, kondisi yang terjadi pada restoran Top Yammie ini disebabkan karena banyaknya usaha seperti restoran, kafe maupun rumah makan yang bermunculan di sekitar wilayah tersebut sehingga berdampak juga pada kondisi penjualan restoran Top Yammie hal ini tentu berdampak pula pada niat perilaku konsumen untuk datang makan pada restoran top yammie semakin menurun. Dari fenomena tersebut dapat diduga ada beberapa hal yang menyebabkan niat perilaku konsumen di restoran Top Yammie menjadi rendah. Hal ini tentu saja dapat memengaruhi behavioral intention (niat perilaku) pada restoran Top Yammie. Menurut Woo Joung et al (2015) behavioral intention merupakan kecenderungan yang dirasakan seseorang atau peluang seseorang akan terlibat dalam suatu perilaku tertentu artinya dengan behavioral intention yang positif, nantinya pihak perusahaan dapat mempetahankan baik itu dari customers lama maupun customers 
baru. Seperti yang terjadi pada restoran Top Yammie di mana restoran ini dalam usaha untuk meningkatkan persaingan antar sesama pelaku bisnis, restoran Top Yammie seharusnya mampu memuaskan pelanggannya melalui kualitas makanan maupun dari kualitas pelayanan sehingga nantinya akan mendapatkan keuntungan perusahaan secara terus menerus. Menurut Shaharudin et al (2011) kualitas makanan merupakan elemen penting dalam sebuah restoran yang meliputi rasa yang enak, presentasi makanan yang menggugah selera, temperatur yang sesuai dan kesegaran makanan sehingga kebutuhan pelanggan dapat terpenuhi. Sehingga dengan kata lain dalam sebuah restoran, produk yang dimaksud adalah makanan. Berdasarkan penelitian yang dilakukan oleh Woo Joung et al (2015) yang berjudul "The Impact of Perceived Service and Food Quality on Behavioral Intentions in Continuing Care Retirement Communities: A Mediating Effect of Satisfaction" dari hasil penelitian tersebut mengatakan bahwa kualitas makanan memiliki pengaruh positif terhadap perilaku pembelian. Oleh karena itu kualitas makanan perlu dijaga agar bisa menciptakan kepuasan pelanggan. berdasarkan hasil wawancara singkat dengan manager restoran di mana pada hari-hari tertentu jumlah pelanggan yang datang meningkat drastis sedangkan staff atau karyawan yang disediakan tidak memadai sehingga membuat pelayanan pada restoran Top Yammie menjadi lama sehingga menyebabkan kepuasan pelanggan menurun. Menurut Canny (2014) kepuasan pelanggan merupakan bagian yang paling penting dalam kegiatan aktivitas bisnis sebab kepuasan pelanggan sebagai penentu sikap dalam pasca pembelian dan mencerminkan sebagai hasil positif atau negatif yang berasal dari pengalaman pribadi konsumen. Penelitian yang dilakukan oleh Canny (2014) yang berjudul "Measuring the Mediating Role of Dining Experience Attributes on Customer Satisfaction and Its Impact on Behavioral Intentions of Casual Dining Restaurant in Jakarta" dalam penelitiannya ingin mencari tahu peranan dalam menyantap makan malam terhadap kepuasan pelanggan dan dampak nya pada perilaku pembelian, dari hasil penelitian tersebut mengatakan bahwa kepuasan pelanggan berpengaruh positif terhadap niat 
perilaku. Selain itu Penelitian yang dilakukan oleh Al-tit (2015) yang berjudul "The Effect of Service and Food Quality On Customer Satisfaction and Hence Customer Satisfaction". Dalam penelitian tersebut ingin mencari tahu hubungan antara kualitas layanan, kualitas makanan, kepuasan pelanggan dan retensi pelanggan restoran di Yordania negara Timur Tengah dari hasil penelitian tersebut menunjukkan bahwa kualitas pelayanan dan kualitas makanan memiliki pengaruh positif pada kepuasan pelanggan. Dari hasil penelitian sebelumnya sudah seharusnya pihak restoran Top Yammie perlu meningkatkan kualitas makanan maupun dari kualitas pelayanannya agar pelanggan yang datang merasa puas dan nantinya niat perilaku pembelian dapat menjadi cara terbaik untuk memprediksikan perilaku pembelian yang akan datang. Oleh karena itu kualitas makanan, kualitas pelayanan dan kepuasaan konsumen sangat dibutuhkan bagi para pelaku usaha untuk dapat memuaskan konsumen secara terus menerus, sehingga niat perilaku pembelian dalam konsumen menjadi tinggi. Karena jika tidak, konsumen restoran Top Yammie semakin lama akan semakin berkurang dan dapat berujung pada kebangkrutan. Sehubungan dengan latar belakang masalah tersebut, maka penulis memutuskan untuk melakukan penelitian dengan judul analisis pengaruh kualitas makanan dan kualitas pelayanan terhadap kepuasan pelanggan dan dampaknya pada behavioral intention restoran Top Yammie. masalah yang dibahas dalam penelitian ini sebagai berikut:

1. Bagaimanakah pengaruh antara kualitas makanan terhadap kepuasan pelanggan pada restoran Top Yammie?

2. Bagaimanakah pengaruh antara kualitas pelayanan terhadap kepuasan pelanggan pada restoran Top Yammie?

3. Bagaimanakah pengaruh antara kualitas makanan terhadap behavioral intention pada restoran Top Yammie?

4. Bagaimanakah pengaruh antara kualitas pelayanan terhadap behavioral intention pada restoran Top Yammie?

5. Bagaimanakah pengaruh 


\author{
antara kepuasan pelanggan \\ terhadap behavioural \\ intention restoran Top \\ Yammie ? \\ 6. Bagaimanakah pengaruh \\ antara kualitas makanan dan \\ kualitas pelayanan terhadap \\ kepuasan pelanggan \\ restoran Top Yammie?
}

7. Bagaimanakah pengaruh antara kualitas makanan dan kualitas pelayanan terhadap kepuasan pelanggan dan dampak pada behavioural intention restoran Top Yammie ?

\section{TELAAH LITERATUR}

Kualitas Makanan

Menurut Kotler dan Armstrong (2012:283) kualitas produk adalah kemampuan sebuah produk dalam memperagakan fungsiya, hal ini termasuk keseluruhan durabilitas, reliabilitas, ketepatan, kemudahan pengoperasian, dan reparasi produk, juga atribut produk lainnya. Menurut Kotler dan Keller (2009:143) kualitas produk adalah totalitas fitur dan karakteristik produk atau jasa yang bergantung pada kemampuannya untuk memuaskan kebutuhan yang dinyatakan atau tersirat. Menurut Potter dan Hotchkiss (2012:1) kualitas makanan adalah karakteristik kualitas dari makanan yang dapat diterima oleh konsumen, seperti ukuran, bentuk, warna, konsistensi, tekstur, dan rasa.
Makanan lezat dan segar memainkan peran penting dalam upaya untuk melampaui pesaing. Dengan demikian, kualitas makanan merupakan salah satu cara terbaik untuk memaksimalkan keberhasilan dalam bisnis restoran. Dalam penelitian ini, beberapa definisi kualitas produk akan diadopsi menjadi kualitas makanan sesuai dengan objek penelitian yang digunakan yaitu restoran Top Yammie.

\section{Dimensi Kualitas Makanan}

Pengukuran kualitas makanan dalam penelitian ini akan menggunakan pengukuran yang diterapkan pada penelitian terdahulu yang dijalankan oleh Rozekhi et al (2016) dengan pengukuran sebagai berikut: 
1. Appealing presentation

Appealing

presentation

mengacu tampilan saat makanan

tersebut disajikan. Semakin

indah dan lengkap makanan,

maka kualitas makanan akan

semakin baik.

2. Menu Variety

Menu variety mengacu pada berbagai macam menu yang di sajikan oleh restoran tersebut. Semakin banyak menu yang variatif maka kualitas makanan pada restoran akan semakin baik.

\section{Healthiness}

Healthiness mengacu pada kebersihan makanan. Semakin higienis dan bergizi makanan yang disajikan oleh sebuah restoran atau kafe, maka akan semakin baik kualitas makanan yang dimiliki oleh kafe itu sendiri.

4. Tastiness

Tastiness mengacu pada kesesuaian cita rasa dan keenakan antara makanan dengan harapan pelanggan. Semakin enak makanan yang disajikan, maka semakin tinggi kualitas makanan yang dimiliki.
5. Freshness

Freshness mengacu pada kesegaran makanan dan dapat dilihat dari warna, serta aroma. Semakin segar makanan yang disajikan, akan semakin mencerminkan kualitas makanan yang baik.

\section{Temperature}

Temperature atau suhu mengacu sejauh mana makanan dapat disajikan sesuai dengan kehangatan atau kedinginan tertentu, misalnya makanan yang seharusnya disajikan dalam keadaan panas, disajikan dalam keadaan yang sesuai, dan tidak dingin.

Pengertian Kualitas Pelayanan (Service Quality)

Menurut Mauludin mengemukakan bahwa kualitas pelayanan adalah seberapa jauh perbedaan antara kenyataan dan harapan pelanggan atas langganan yang mereka terima atau peroleh. Menurut Parasuraman (dalam Sangadji dan Sopiah 2013:100) mendefinisikan kualitas pelayanan sebagai tingkat keunggulan yang diharapkan dan pengendalian atas tingkat keunggulan 
tersebut untuk memenuhi keinginan pelanggan. Sedangkan menurut Suwithi et al (dalam Anwar 2012:94) kualitas pelayanan adalah mutu dari pelayanan yang diberikan kepada pelanggan, baik pelanggan internal maupun pelanggan eksternal berdasarkan standar prosedur pelayanan. Dari definisi diatas dapat disimpulkan bahwa kualitas pelayanan adalah suatu kegiatan yang di berikan oleh perusahaan untuk konsumen agar konsemen merasa nyaman dan kemampuan perusahaan untuk menciptakan hubungan yang baik dan konsisten dengan konsumen.

\section{Dimensi Service Quality}

Menurut Haghighi et al (2012) mengatakan ada beberapa dimensi dalam kualitas pelayanan antara lain sebagai berikut:

\section{Reliability}

Merupakan kemampuan untuk mewujudkan layanan yang dijanjikan dapat diandalkan dan dilaksanakan secara akurat

2. Responsiveness

Merupakan kemauan untuk membantu dan menyediakan jasa yang tepat waktu bagi konsumen.

\section{Competence}

Pengetahuan dan keramahan pegawai serta kemampuan untuk merebut kepercayaan dan keyakinan konsumen

\section{Friendliness}

Merupakan kepedulian dan perhatian per individu yang di terapkan badan usaha dalam menghadapi konsumennya.

Kepuasan Pelanggan

Menurut Kotler dan Armstrong (2012:37) mengatakan bahwa kepuasan pelanggan adalah tingkat dimana kinerja yang dirasakan dari suatu produk sesuai dengan ekspektasi pelanggan. Suatu perusahaan akan berusaha membuat pelanggan senang dengan menjanjikan apa yang mereka dapat berikan dan memberikan apa yang mereka janjikan. Pelanggan yang senang tidak hanya akan melakukan pembelian ulang tetapi akan membantu menjadi teman yang akan menyebarkan pengalaman positif mereka. Menurut Kotler dan Armstrong (dalam Sunyoto 2013:35) kepuasan konsumen adalah tingkat perasaan seseorang setelah membandingkan (kinerja atau hasil) yang dirasakan dibandingkan dengan harapannya. 
Konsumen dapat mengalami salah satu dari tiga tingkat kepuasan umum yaitu kalau kinerja di bawah harapan, konsumen akan merasa kecewa tetapi jika kinerja sesuai dengan harapan pelanggan akan merasa puas dan apa bila kinerja bisa melebihi harapan maka pelanggan akan merasakan sangat puas senang atau gembira. Menurut Giese dan Cote yang (dalam Tjiptono \& Chandra 2011:292) mengatakan bahwa kepuasan pelanggan memiliki kesamaan dalam hal tiga komponen sebagai berikut:

1. Kepuasan pelanggan merupakan respon (emosional atau kognitif)

2. Respon tersebut menyangkut fokus tertentu (ekspektasi, produk, dan pengalaman konsumsi)

3. Respon terjadi pada waktu tertentu (setelah konsumsi, setelah pemilihan produk atau jasa, berdasarkan pengalaman akumulatif, dan lain-lain)

Dari definisi di atas, maka dapat di peroleh unsur kesamaan yaitu perasaan, konsumen dan perbandingan dari unsur persamaan tersebut dapat disimpulkan bahwa kepuasan konsumen adalah perasaan pelanggan terhadap evaluasi ketidaksesuaian (disconfirmation) saat pembelian produk yang dirasakan antara harapan sebelumnya dan kinerja aktual produk yang dirasakan setelah pemakaiannya.

Keputusan Pembelian

Menurut Kotler dan Armstrong (2012:157) keputusan pembelian adalah pola perilaku pembelian akhir dari konsumen, baik individual, maupun rumah tangga yang membeli barang dan jasa untuk konsumsi pribadi. Menurut Kotler dan Keller (2012:166) Keputusan pembelian adalah keputusan yang diambil konsumen untuk melakukan pembelian suatu produk melalui tahapan-tahapan yang dilalui konsumen sebelum melakukan pembelian yang meliputi kebutuhan yang dirasakan, kegiatan sebelum membeli, perilaku waktu memakai, dan perasaan setelah membeli. Menurut Schiffman dan Kanuk (dalam Kalangi 2010:29) mendefinisikan keputusan pembelian adalah pemilihan suatu tindakan dari dua atau lebih pilihan alternatif. Dari definisi di atas terdapat unsur kesamaan yaitu konsumen, perilaku dan pembelian. Maka dari 
definisi di atas dapat di simpulkan bahwa keputusan pembelian adalah perilaku dalam melakukan pembelian barang dan jasa dalam waktu tertentu untuk di konsumsi.

Dimensi Kepuasan Konsumen

Menurut Canny (2014) mengatakan bahwa ada beberapa dimensi dalam kepuasan konsumen antara lain meliputi:

\section{Satisfied with this restaurant}

Pelanggan merasa puas terhadap apapun yang di berikan pada restoran tersebut baik dari segi kualitas makanan atau pun pelayanan.

2. Visited this restaurant

Pelanggan merasa senang ketika berkunjung ke restoran tersebut.

3. Enjoyed at this restaurant Pelanggan menikmati ketika berkunjung ke restoran.

\section{Pengertian Behavioral Intention}

Menurut Takahashi et al (2011:5) mengatakan bahwa (behavioral intention) merupakan model untuk menjelaskan minat perilaku konsumen, yang menunjukkan bahwa minat perilaku dapat ditangkap oleh minat pembelian kembali, word-of-mouth, loyalitas, perilaku dalam memberikan komplain, dan sensitivitas harga. Menurutnya, semakin besar pengalaman pelanggan yang lebih positif, maka semakin besar kemungkinan dia bersedia untuk menggunakan kembali layanan tersebut. Menurut Schiffman \& Kanuk (2010:235), niat berperilaku (behavioral intention) adalah frekuensi pembelian atau proporsi pembelian total dari pembeli yang setia terhadap merek tertentu.

Sedangkan Menurut Canny (2014) behavioral intention merupakan tingkat dimana seseorang telah mengungkapkan rencana sadar untuk melakukan atau tidak melakukan beberapa perilaku masa depan tertentu yang sering disebut juga sebagai tujuan perilaku.

Dari definisi di atas, maka dapat di peroleh unsur kesamaan yaitu perilaku, pengunjung dan pembelian masa akan datang. Dari unsur persamaan tersebut dapat disimpulkan bahwa behavioural intention adalah keinginan konsumen untuk berperilaku menurut cara tertentu dalam rangka memiliki dan menggunakan produk atau jasa secara terus menerus baik sekarang maupun yang akan datang. 
Dimensi Behavioral Intention

Menurut Canny (2014) ada beberapa dimensi behavioral intention antara lain meliputi:

\section{Revisit Intention}

Ketersedian pelanggan untuk datang kembali ke Restoran ini di masa depan.

\section{Say Positive Thing}

\section{METODOLOGI PENELITIAN}

Penelitian ini menggunakan penelitian asosiatif. Penelitian asosiatif merupakan penelitian yang bertujuan untuk mengetahui hubungan antara dua variabel atau lebih. Dengan penelitian ini maka akan dapat dibangun suatu teori yang dapat berfungsi untuk menjelaskan, meramalkan, dan mengontrol suatu gejala. Pada penelitian ini penulis melakukan peneltian langsung pada restoran Top Yammie yang berlokasi di jalan Labu No. 5, Mangga Besar Taman Sari Jakarta Barat. Populasi dalam penelitian ini adalah para pelanggan Restoran Top Yammie di Jakarta Barat, sedangkan sampel adalah sebagian dari populasi itu sendiri. Di mana ukuran sampel merupakan langkah untuk menentukan besarnya jumlah sampel yang akan diambil untuk melaksanakan penelitian suatu objek, kemudian besarnya sampel
Keinginan pelanggan untuk mengatakan hal-hal positif tentang restoran ini kepada orang lain.

\section{Recommend the Restaurant}

Kesediaan pelanggan untuk merekomendasikan restoran ini ke teman atau orang lain.

tersebut biasanya diukur secara statistika ataupun estimasi penelitian. Meskipun sampel hanya merupakan bagian dari populasi, kenyataankenyataan yang diperoleh dari sampel itu dapat menggambarkan dalam populasi oleh karena itu sample yang di gunakan penelitian adalah sebagian dari pelanggan yang datang ke Restoran Top Yammie. Berdasarkan hasil wawancara yang di dapat dengan manager restoran hasil pengunjung yang datang pada bulan Desember jumlah pelanggan yang makan pada tahun 2018 selama satu minggu terakhir adalah 1592 orang. Pada penelitian ini penulis menggunakan teknik probability sampling dengan menggunakan simple random sampling yaitu cara pengambilan sampel secara acak dari anggota populasi tanpa memperdulikan tingkatan. Dalam penelitian ini, sampel yang diambil adalah orang yang makan 
di restoran Top Yammie. Dalam menggunakan rumus Slovin di mana menentukan jumlah sampel yang rumus tersebut yaitu:

diambil dalam penelitian ini penulis

$$
\begin{array}{rl}
\mathrm{n}= & \frac{\mathrm{N}}{\text { responden }}= \\
\quad \mathrm{N} \cdot \mathrm{d}^{2}+1 & 1592 \times(0.1)^{2}+1
\end{array}
$$

\section{Keterangan:}

$$
\begin{array}{ll}
\mathrm{n} & =\text { Jumlah Sampel } \\
\mathrm{N} & =\text { Jumlah Populasi } \\
\mathrm{d}^{2} & =\text { Presisi yang ditetapkan (sebesar 10\%) }
\end{array}
$$

Dari hasil perhitungan sampel di atas, maka jumlah sampel yang akan digunakan dalam penelitian ini adalah 100 responden yang pernah makan ke restoran Top Yammie. Dalam pengujiannya penlulis menggunakan path analysis atau analisis jalur. Path analysis adalah teknik untuk menganalisis hubungan sebab akibat yang terjadi pada regresi berganda jika variabel bebasnya memengaruhi variabel terikat tidak hanya secara langsung tetapi juga secara tidak langsung. Path Analysis digunakan untuik menganalisis pola hubungan antar variabel dengan tujuan untuk mengetahui pengaruh langsung maupun tidak langsung seperangkat variabel bebas (eksogen) terhadap variabel terikat (endogen). Model struktural yaitu bila setiap variabel endogen $(\mathrm{Y})$ secara unik keadaannya ditentukan oleh seperangkat variabel eksogen (X). model penggambarannya seperti di bawah berikut: 
Gambar 1 Model Sub-struktur 1

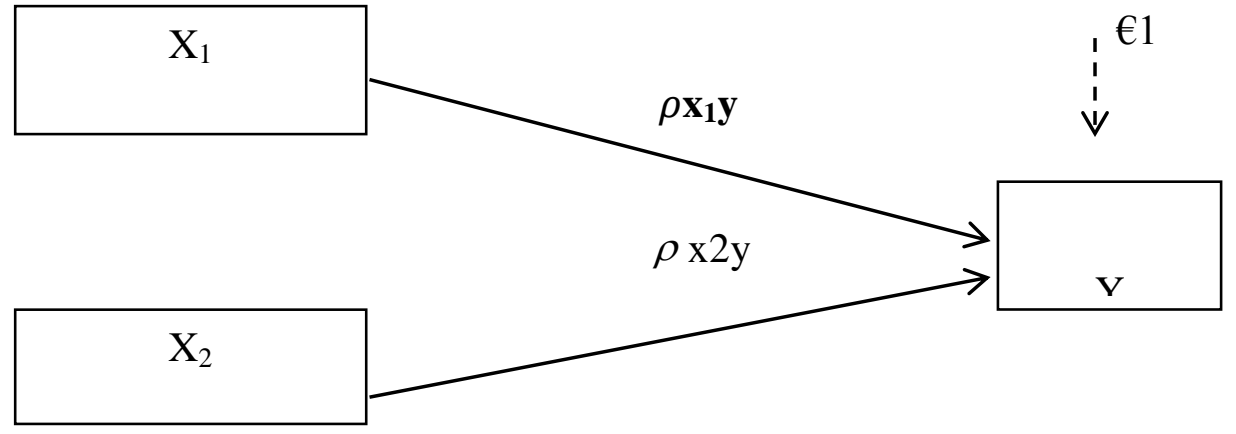

\section{Untuk T-1}

Hipotesis :

Ho : Tidak ada pengaruh signifikan antara kulitas makanan terhadap kepuasan pelanggan

$\mathrm{Ha}$ : Ada pengaruh signifikan antara kualitas makanan terhadap kepuasan pelanggan

\section{Untuk T-2}

Hipotesis :

Ho : Tidak ada pengaruh signifikan antara kulitas pelayanan terhadap kepuasan pelanggan

$\mathrm{Ha}$ : Ada pengaruh signifikan antara kualitas pelayanan terhadap kepuasan pelanggan

Gambar 2 Model Sub-struktur 2

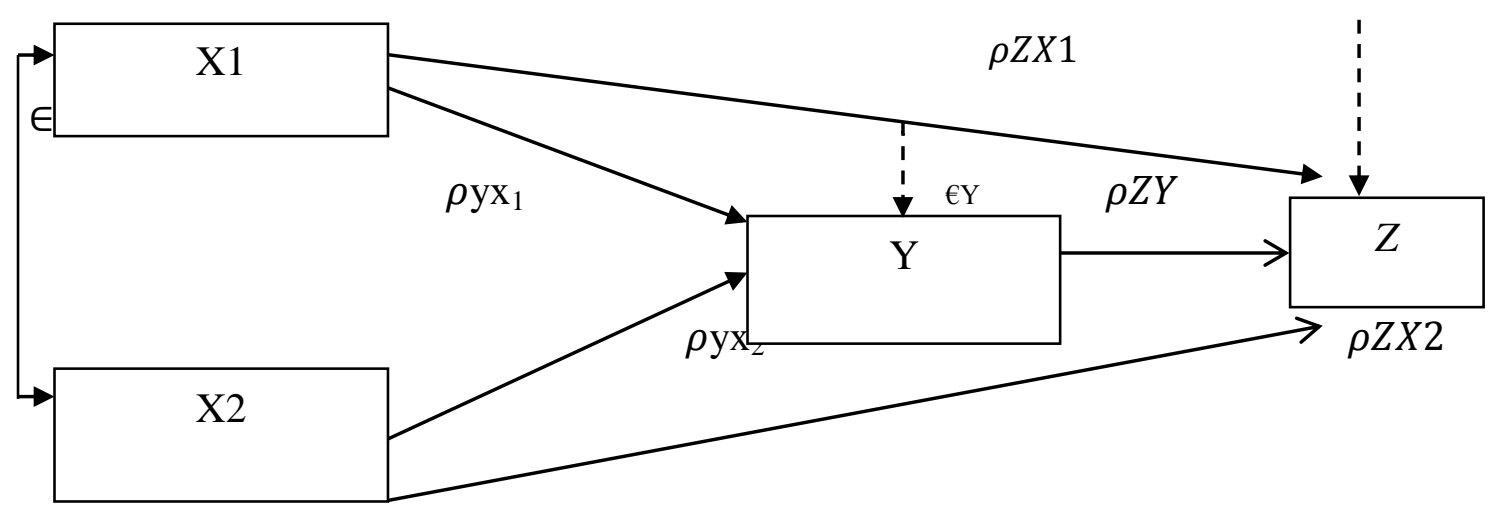


Pengujian antara $\mathrm{X}$ terhadap $\mathrm{Z}$ melalui $\mathrm{Y}$

Untuk T-3

Hipotesis :

Ho : Tidak ada pengaruh signifikan antara kulitas makanan terhadap behavioral intention.

Ha : Ada pengaruh signifikan antara kualitas makanan terhadap behavioral intention.

Untuk T-4

Hipotesis :

Ho : Tidak ada pengaruh signifikan antara kulitas pelayanan terhadap behavioral intention.

$\mathrm{Ha}$ : Ada pengaruh signifikan antara kualitas pelayanan terhadap behavioral intention.

Untuk T-5

Hipotesis :

Ho : Tidak ada pengaruh signifikan antara kepuasan pelanggan terhadap behavioral intention.
Ha : Ada pengaruh signifikan antara kepuasan pelanggan terhadap behavioral intention.

Untuk T-6

Hipotesis :

Ho : Tidak ada pengaruh signifikan antara kualitas makanan, kualitas pelayanan terhadap kepuasan pelanggan.

Ha : Ada pengaruh signifikan antara kualitas makanan, kualitas pelayanan terhadap kepuasan pelanggan.

\section{Untuk T-7}

Hipotesis :

Ho : Tidak ada pengaruh signifikan antara kualitas makanan, kualitas pelayanan terhadap kepuasan pelanggan dan dampaknya pada behavioral intention.

Ha : Ada pengaruh signifikan antara kualitas makanan, kualitas pelayanan terhadap kepuasan pelanggan dan dampaknya pada behavioral intention.

Persamaan struktural untuk diagram jalur yaitu :

$\mathrm{Y}=\rho_{\mathrm{YX}} \mathrm{X} 1+\rho_{\mathrm{YX}} X 2+\varepsilon 1$ (persamaan sub-struktural 1)

$Z=\rho z \mathrm{X} 1+\rho z X 2+\rho Z y+\varepsilon 1$ (persamaan sub-struktural 2)

Keterangan:

$\rho=$ koefisien jalur (path coefficient), yang menunjukkan pengaruh langsung variabel eksogen terhadap variabel endogen 
$\varepsilon=$ faktor residual, yang menunjukkan pengaruh variabel lain yang tidak diteliti atau kekeliruan pengukuran variabel

Kategori seberapa besar pengaruh dari nilai koefisien beta akan diuraikan variabel independen terhadap variabel pada tabel 5 berikut ini : dependen dalam Path Analysis dilihat

Tabel 1 Kategori Hubugan Pengaruh Variabel Yang Diteliti

\begin{tabular}{cc} 
Interval Koefisien jalur & Tingkat Kontribusi \\
$\mathbf{0 , 0 5 - 0 , 0 9}$ & Lemah \\
$\mathbf{0 , 1 0 - 0 , 2 9}$ & Sedang \\
$>\mathbf{0 . 3 0}$ & Kuat \\
\hline
\end{tabular}

Sumber : Suwarno (dalam Sarjono dan Julianita, 2011:117)

\section{PEMBAHASAN}

Pengujian sub-struktur 1 digunakan untuk mengukur pengaruh dari kualitas makanan dan kualitas pelayanan terhadap kepuasan pelanggan pada restoran Top Yammie. Berikut ini ditampilkan hasil dari pengujian substruktur 1 dengan menggunakan bantuan program SPSS analisis pengaruh kualitas makanan dan kualitas pelayanan terhadap kepuasan pelanggan.

Hasil Model Summary Kualitas Makanan ( $\left.\mathrm{X}_{1}\right)$ Dan Kualitas Pelayanan $\left(\mathrm{X}_{2}\right)$ Terhadap Kepuasan Pelanggan (Y)

Tabel 2 Hasil Model Summary ${ }^{\mathrm{b}}$

\begin{tabular}{|c|c|c|c|c|}
\hline Model & $\mathbf{R}$ & $\begin{array}{c}\text { R } \\
\text { Square }\end{array}$ & $\begin{array}{l}\text { Adjusted R } \\
\text { Square }\end{array}$ & $\begin{array}{l}\text { Std. Error of } \\
\text { the Estimate }\end{array}$ \\
\hline & $.596^{\mathrm{a}}$ & .355 & .343 & .51442 \\
\hline & $\begin{array}{l}\text { ctors: } \\
\text { akanan }\end{array}$ & (Const & Kual & tas_Pelayanan, \\
\hline
\end{tabular}


Berdasarkan tabel tersebut nilai $\mathrm{R}$ Square sebesar 0,355 yang artinya besarnya pengaruh antara variabel kualitas makanan $\left(\mathrm{X}_{1}\right)$ dan kualitas pelayanan $\left(\mathrm{X}_{2}\right) \quad$ mempengaruhi kepuasan pelanggan (Y) sebesar 0,355
$(35,5 \%)$ dan sisanya sebesar 0,645 $(64,5 \%)$ dipengaruhi oleh variabel lainnya diluar penelitian ini. Berikut ini besarnya koefisien jalur untuk variabel lain diluar dari penelitian ditentukan dengan persamaan sebagai berikut :

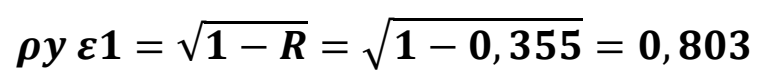

Hasil Anova Kualitas Makanan $\left(\mathrm{X}_{1}\right)$ Dan Kualitas Pelayanan $\left(\mathrm{X}_{2}\right)$ Terhadap Kepuasan Pelanggan (Y)

Tabel 3 Hasil Uji ANOVA ${ }^{\mathrm{a}}$

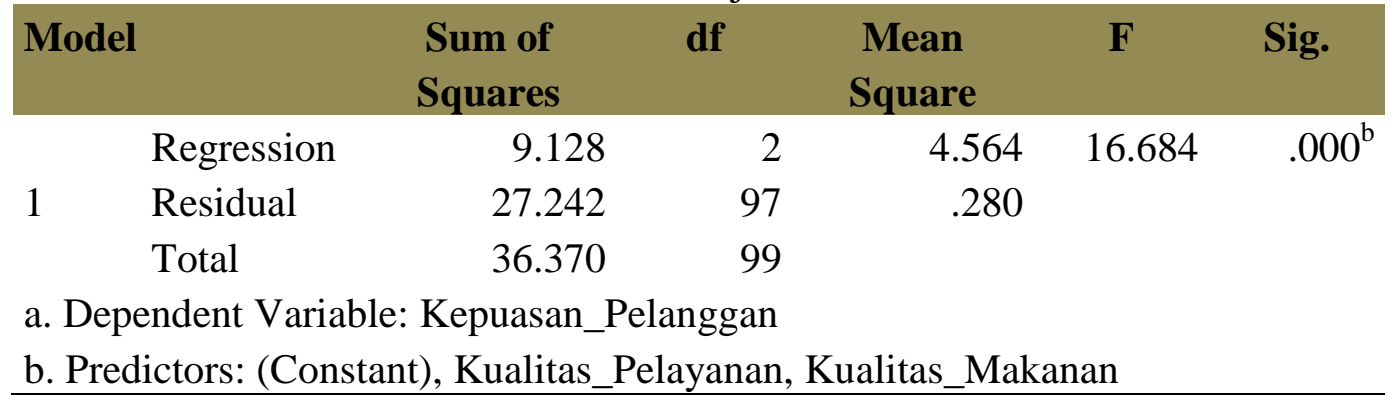

Hipotesis

Ho : tidak ada pengaruh kualitas makanan dan kualitas pelayanan secara simultan dan signifikan terhadap kepuasan pelanggan.

Ha : ada pengaruh kualitas makanan dan kualitas pelayanan secara simultan dan signifikan terhadap kepuasan pelanggan.

Dasar Pengambilan Keputusan :
Jika angka Sig. $\geq 0,10$, maka $\mathrm{H} 0$ diterima dan Ha ditolak

Jika angka Sig. <0,10, maka H0 ditolak dan Ha diterima

Hasil :

Uji Sig. $=0,000<0,10$, maka $\mathrm{H} 0$ ditolak dan Ha diterima

Kesimpulan :

Hasil uji signifikansi pada tabel anova sebelumnya menunjukan nilai sig sebesar 0,000 di mana $0,000<0,10$ 
dengan demikian Ho ditolak dan $\mathrm{Ha}$ diterima. artinya koefisien regresi adalah signifikan. Kesimpulan menunjukan bahwa kualitas makanan dan kualitas pelayanan berpengaruh simultan dan signifikan terhadap terhadap kepuasan pelanggan.

Hasil Coeffients Kualitas Makanan $\left(\mathrm{X}_{1}\right)$ Dan Kualitas Pelayanan $\left(\mathrm{X}_{2}\right)$ Terhadap Kepuasan Pelanggan (Y)

Tabel 4 Hasil Uji Coefficients ${ }^{a}$

\begin{tabular}{|c|c|c|c|c|c|c|}
\hline \multirow{2}{*}{\multicolumn{2}{|c|}{ Model }} & \multicolumn{2}{|c|}{$\begin{array}{l}\text { Unstandardized } \\
\text { Coefficients }\end{array}$} & \multirow{2}{*}{$\begin{array}{l}\text { Standardized } \\
\text { Coefficients } \\
\text { Beta }\end{array}$} & \multirow[t]{2}{*}{ t } & \multirow[t]{2}{*}{ Sig. } \\
\hline & & B & Std. Error & & & \\
\hline \multirow[b]{3}{*}{1} & Constant) & 1.539 & .485 & & 3.683 & .004 \\
\hline & Kualitas_Makanan & .527 & .128 & .389 & 4.193 & .000 \\
\hline & Kualitas_Pelayana & .225 & .101 & .027 & 2.375 & .029 \\
\hline Deper & dent Variable: Ker & Pelan: & & & & \\
\hline
\end{tabular}

Pengujian secara individual antara

Nilai t-tabel dilihat pada taraf kualitas makanan $\left(\mathrm{X}_{1}\right)$ dan kepuasan pelanggan $(\mathrm{Y})$

Uji t

Hipotesis :

$\mathrm{H}_{0}$ : Tidak ada pengaruh antara kualitas makanan terhadap kepuasan pelanggan.

Ha: Ada pengaruh antara kualitas makanan terhadap kepuasan pelanggan.

Dasar Pengambilan Keputusan :

Jika thitung < ttabel, maka $\mathrm{H}^{0}$ diterima dan Ha ditolak

Jika thitung $\geq$ ttabel, maka $\mathrm{H}^{0}$ ditolak dan Ha diterima

signifikansi 0,10 di mana $\mathrm{df}=$ jumlah sampel- jumlah variabel $=100-2=98$. Oleh karena itu, nilai ttabel pada $\mathrm{df}=98$ adalah 1,29. Nilai thitung diperoleh pada tabel coefficients, di mana dari tabel coefficients sebelumnya diketahui bahwa besar thitung variabel kualitas makanan $\left(\mathrm{X}_{1}\right)$ dan $\mathrm{Y}$ adalah 4.193. artinya thitung $\geq \mathrm{t}$-tabel $(4,193>1,29)$. Dengan demikian, Ho ditolak dan Ha diterima yang memberikan kesimpulan bahwa variabel kualitas makanan $\left(\mathrm{X}_{1}\right)$ berpengaruh secara individu terhadap variabel $\mathrm{Y}$. 
Uji Signifikansi secara individual

Hipotesis

Ho : kualitas makanan tidak berkontribusi secara signifikan terhadap kepuasan pelanggan.

Ha : kualitas makanan berkontribusi secara signifikan terhadap kepuasan pelanggan.

Dasar Pengambilan Keputusan :

Jika angka Sig. $\geq 0,10$ maka $\mathrm{H} 0$ diterima dan Ha ditolak

Jika angka Sig. < 0,10 maka H0 ditolak dan Ha diterima

Hasil :

Uji Sig. $=0,000<0,10$, maka Ho ditolak dan Ha diterima

Kesimpulan :

Dari tabel coefficients, diketahui bahwa variabel kualitas makanan $\left(\mathrm{X}_{1}\right)$ mempunyai nilai Sig sebesar 0,000 jika dibandingkan dengan taraf signifikansi 0,10 maka nilai sig lebih kecil daripada nilai taraf signifikansi $(0,000<0,10)$. Artinya Ho ditolak dan Ha diterima ( signifikan) dan besarnya beta (koefisien jalur) variabel kualitas makanan $\left(\mathrm{X}_{1}\right)$ terhadap kepuasan pelanggan (Y) adalah 0,389 .

Pengujian secara individual antara kualitas pelayanan $\left(\mathrm{X}_{2}\right)$ dan kepuasan pelanggan (Y)

\section{Uji t}

Hipotesis :

$\mathrm{H}_{0} \quad$ : Tidak ada pengaruh antara kualitas pelayanan terhadap kepuasan pelanggan.

Ha : Ada pengaruh antara kualitas pelayanan terhadap kepuasan pelanggan.

Dasar Pengambilan Keputusan :

Jika $\mathrm{t}$ hitung < t-tabel, maka H0 diterima dan Ha ditolak

Jika t hitung $\geq$ t-tabel, maka H0 ditolak dan Ha diterima

Nilai t-tabel dilihat pada taraf signifikansi 0,10 di mana $\mathrm{df}=$ jumlah sampel - jumlah variabel $=100-2=98$. Oleh karena itu, nilai ttabel pada df $=98$ adalah 1,29. Nilai thitung diperoleh pada tabel coefficients, di mana dari tabel coefficients sebelumnya diketahui bahwa besar thitung variabel kualitas pelayanan $\left(\mathrm{X}_{2}\right)$ dan $\mathrm{Y}$ adalah 2,375. artinya thitung $\geq$ ttabel $(2,375>1,29)$. Dengan demikian, Ho ditolak dan $\mathrm{Ha}$ diterima yang memberikan kesimpulan bahwa variabel kualitas pelayanan $\left(\mathrm{X}_{2}\right)$ berpengaruh secara individu terhadap variabel Y. 
Uji Signifikansi secara individual

Hipotesis

Ho : kualitas pelayanan tidak berkontribusi secara signifikan terhadap kepuasan pelanggan.

Ha : kualitas pelayanan berkontribusi secara signifikan terhadap kepuasan pelanggan.

Dasar pengambilan keputusan jika angka Sig. $\geq 0,10$ maka $\mathrm{H}_{0}$ diterima dan Ha ditolak, jika angka Sig. $<0,10$ maka $\mathrm{H}_{0}$ ditolak dan $\mathrm{Ha}$ diterima, maka hasil nya uji Sig. $=0,029<0,10$, maka Ho ditolak dan Ha diterima
Dari tabel coefficients, dapat diketahui di mana bahwa variabel kualitas pelayanan $\left(\mathrm{X}_{2}\right)$ mempunyai nilai Sig sebesar 0,029 jika dibandingkan dengan taraf signifikansi 0,10 maka nilai sig lebih kecil daripada nilai taraf signifikansi $(0,029<0,10)$. Artinya Ho ditolak dan Ha diterima (signifikan) dan besarnya beta (koefisien jalur) variabel kualitas pelayanan $\left(\mathrm{X}_{2}\right)$ terhadap kepuasan pelanggan (Y) adalah 0,027 ( $\left.\rho_{Y} \mathrm{X} 2\right)$

Tabel 5 Hasil Rangkuman Pengujian Sub-Struktur 1

\begin{tabular}{cccccc}
$\begin{array}{c}\text { Pengaruh } \\
\text { Antar }\end{array}$ & $\begin{array}{c}\text { Koefisien } \\
\text { Jalur }\end{array}$ & Sig. & $\begin{array}{c}\text { Pengujian } \\
\text { Hipotesis }\end{array}$ & $\begin{array}{c}\text { Koefisien } \\
\text { Determinasi }\end{array}$ & $\begin{array}{c}\text { Koefisien } \\
\text { Variabel } \\
\text { Lain } \\
(\boldsymbol{\rho} \boldsymbol{\varepsilon} \boldsymbol{\varepsilon} \mathbf{1})\end{array}$ \\
$\mathrm{X}_{1}$ terhadap Y & 0,389 & 0,000 & $\mathrm{H}_{\mathrm{a}}$ Diterima & $0,355(35,5 \%)$ & 0,803 \\
$\mathrm{X}_{2}$ terhadap Y & 0,027 & 0,029 & $\mathrm{H}_{\mathrm{a}}$ Diterima & $0,355(35,5 \%)$ & 0,803 \\
\hline
\end{tabular}

Dengan demikian maka dapat jalur sub-struktur 1 dengan ditampilkan digambarkan atau dapat dibuat hasil nilai koefisien regresi sebagai berikut: rangkuman oleh penulis untuk diagram 
Gambar 3 Sub-Struktur 1 beserta koefisien jalur

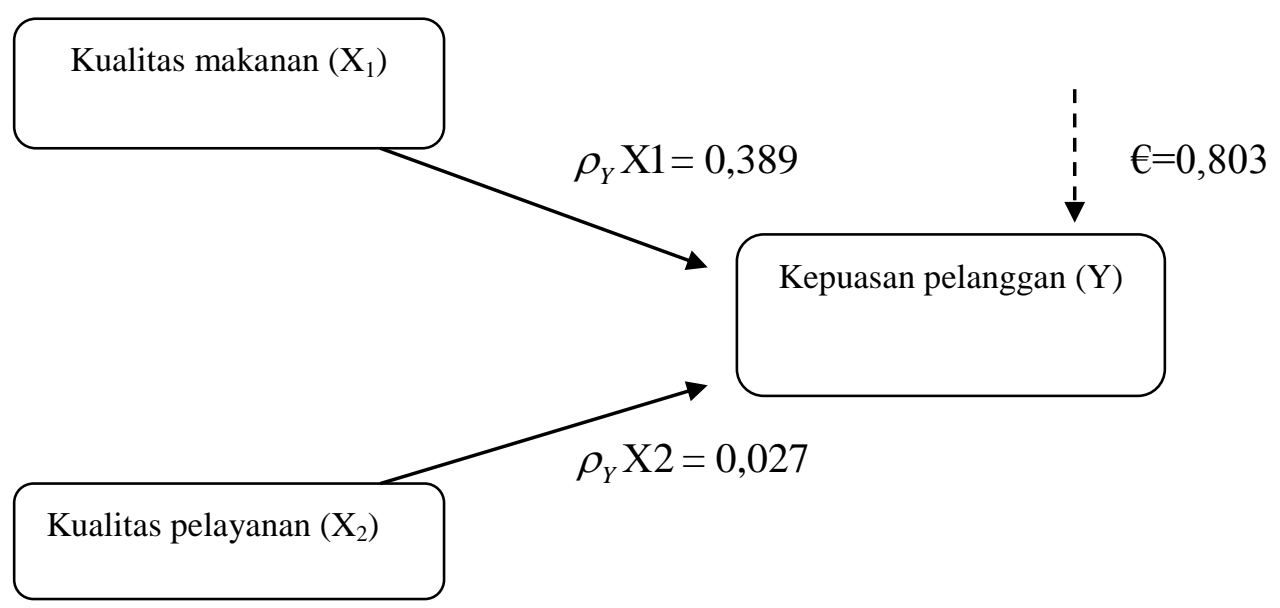

Diperoleh persamaan sub-struktur 1 :

$\mathrm{Y}=\rho_{Y X} 1+\rho_{Y X} 2+\rho_{Y} \varepsilon_{1}$ $\mathrm{Y}=0,389 X 1+0,027 X 2+0,803 \varepsilon_{1}$ di mana $\mathrm{R}^{2}=0,355$

\section{Pengujian Sub-Struktur 2}

Selanjutnya dalam pengujian substruktur 2 digunakan untuk mengukur pengaruh dari kualitas makanan dan kualitas pelayanan terhadap kepuasan pelanggan dan dampaknya pada behavioral intention pada restoran Top
Yammie. Berikut ini ditampilkan hasil dari pengujian sub-struktur 2 dengan menggunakan bantuan program SPSS analisis pengaruh kualitas makanan dan kualitas pelayanan terhadap kepuasan pelanggan dan dampaknya pada behavioral intention.

Hasil Model Summary Kualitas Makanan $\left(\mathrm{X}_{1}\right)$ Dan Kualitas Pelayanan $\left(\mathrm{X}_{2}\right)$ Terhadap Kepuasan Pelanggan (Y) Dan Dampaknya Pada Behavioral Intention (Z)

Tabel 6 Hasil Uji Model Summary ${ }^{\text {b }}$

\begin{tabular}{lcccr} 
Model & $\mathbf{R}$ & $\begin{array}{c}\text { R } \\
\text { Square }\end{array}$ & $\begin{array}{c}\text { Adjusted R } \\
\text { Square }\end{array}$ & $\begin{array}{r}\text { Std. Error of } \\
\text { the Estimate }\end{array}$ \\
1 & $.876^{\mathrm{a}}$ & .767 & .749 & .40797 \\
a. & Predictors: & (Constant), & kepuasan_pelanggan, \\
Kualitas_pelayanan, Kualitas_makanan & \\
b. Dependent Variable: behavioral_intention \\
\hline
\end{tabular}


Berdasarkan Tabel di atas nilai $R$ Square sebesar 0,767 yang artinya besarnya pengaruh antara variabel kualitas makanan $\left(\mathrm{X}_{1}\right)$ dan kualitas pelayanan $\left(\mathrm{X}_{2}\right) \quad$ mempengaruhi kepuasan pelanggan (Y) dan dampaknya pada behavioral intention sebesar $0,767 \quad(76,7 \%)$ dan sisanya sebesar 0,23,3 (23,3\%) dipengaruhi oleh variabel lainnya diluar penelitian ini. Berikut ini besarnya koefisien jalur untuk variabel lain diluar dari penelitian ditentukan dengan persamaan sebagai berikut :

$$
y \varepsilon 1=\sqrt{1-R}=\sqrt{1-0,767}=0,482
$$

Hasil Anova Kualitas Makanan $\left(\mathrm{X}_{1}\right)$ Dan Kualitas Pelayanan $\left(\mathrm{X}_{2}\right)$ Terhadap Kepuasan Pelanggan (Y) Dan Dampaknya Pada Behavioral Intention (Z)

Tabel 7 Hasil Uji ANOVA ${ }^{\mathrm{a}}$

\begin{tabular}{rlrrrrr} 
Model & & \multicolumn{1}{c}{$\begin{array}{c}\text { Sum of } \\
\text { Squares }\end{array}$} & df & \multicolumn{1}{c}{$\begin{array}{c}\text { Mean } \\
\text { Square }\end{array}$} & \multicolumn{1}{c}{ F } & Sig. \\
& Regression & 16.722 & 3 & 5.574 & 121.147 & $.000^{\mathrm{b}}$ \\
1 & Residual & 8.280 & 96 & .086 & & \\
& Total & 25.002 & 99 & & &
\end{tabular}

a. Dependent Variable: behavioral_intention

b. Predictors: (Constant), kepuasan_pelanggan, Kualitas_pelayanan, Kualitas_makanan

Uji Sig

Hipotesis

Ho : tidak ada pengaruh kualitas makanan, kualitas pelayanan dan kepuasan pelanggan secara simultan dan signifikan terhadap behavioral intention.

Ha : ada pengaruh kualitas makanan, kualitas pelayanan dan kepuasan pelanggan secara simultan dan signifikan terhadap behavioral intention. dasar pengambilan keputusan jika angka sig. $\geq 0,10$, maka $\mathrm{H}_{0}$ diterima dan Ha ditolak, sedangkan jika angka Sig. < 0,10, maka H0 ditolak dan Ha diterima Hasil Uji Sig. = 0,000<0,10, maka H0 ditolak dan Ha diterima

Kesimpulannya maka hasil uji signifikansi pada tabel anova sebelumnya menunjukan nilai sig sebesar 0,000 di mana $0,000<0,10$ dengan demikian $\mathrm{Ho}$ ditolak dan $\mathrm{Ha}$ 
diterima. artinya koefisien regresi pelanggan berpengaruh simultan dan adalah signifikan. Kesimpulan menunjukan bahwa kualitas makanan signifikan terhadap terhadap behavioral dan kualitas pelayanan dan kepuasan intention.

Hasil Coeffients Kualitas Makanan ( $\left.\mathrm{X}_{1}\right)$ Dan Kualitas Pelayanan $\left(\mathrm{X}_{2}\right)$ Terhadap Kepuasan Pelanggan (Y) Dan Dampaknya Pada Behavioral Intention (Z)

Tabel 8 Hasil Uji Coefficients ${ }^{\mathrm{a}}$

\begin{tabular}{|c|c|c|c|c|c|c|}
\hline \multirow{2}{*}{\multicolumn{2}{|c|}{ Model }} & \multicolumn{2}{|c|}{$\begin{array}{l}\text { Unstandardized } \\
\text { Coefficients }\end{array}$} & \multirow{2}{*}{$\begin{array}{c}\text { Standardize } \\
\text { d }\end{array}$} & \multirow[t]{2}{*}{$\mathbf{t}$} & \multirow[t]{2}{*}{ Sig. } \\
\hline & & B & Std. Error & & & \\
\hline \multirow{4}{*}{1} & (Constant) & -.463 & .413 & & -.651 & .662 \\
\hline & Kualitas_makanan & .255 & .063 & .351 & 4.708 & .018 \\
\hline & Kualitas_pelayanan & .169 & .087 & .139 & 2.190 & .037 \\
\hline & kepuasan_pelanggan & .684 & .092 & .698 & 7.469 & .000 \\
\hline \multicolumn{7}{|c|}{ a. Dependent Variable: behavioral_intention } \\
\hline
\end{tabular}

Pengujian secara individual antara kualitas makanan $\left(\mathrm{X}_{1}\right)$ dan behavioral intention $(\mathrm{Z})$

Uji t

\section{Hipotesis :}

$\mathrm{H}_{0}$ : Tidak ada pengaruh antara kualitas makanan terhadap behavioral intention.

Ha: Ada pengaruh antara kualitas makanan terhadap behavioral intention.

Dasar Pengambilan Keputusan :

Jika thitung $<$ ttabel, maka $\mathrm{H}_{0}$ diterima dan Ha ditolak, Jika thitung $\geq$ ttabel, maka H0 ditolak dan Ha diterima

Nilai ttabel dilihat pada taraf signifikansi 0,10 di mana $\mathrm{df}=$ jumlah sampel- jumlah variabel $=100-2=98$.
Oleh karena itu, nilai ttabel pada df $=98$ adalah 1,29. Nilai t-hitung diperoleh pada tabel coefficients, di mana dari tabel coefficients sebelumnya diketahui bahwa besar thitung variabel kualitas makanan $\left(\mathrm{X}_{1}\right)$ dan $\mathrm{Z}$ adalah 4.708. artinya thitung $\geq$ ttabel $(4,708>1,29)$. Dengan demikian, Ho ditolak dan $\mathrm{Ha}$ diterima yang memberikan kesimpulan bahwa variabel kualitas makanan $\left(\mathrm{X}_{1}\right)$ berpengaruh secara individu terhadap variabel Z.

Uji Signifikansi secara individual Hipotesis 
Ho : kualitas makanan tidak berkontribusi secara signifikan terhadap behavioral intention.

Ha : kualitas makanan berkontribusi secara signifikan terhadap behavioral intention.

Dasar Pengambilan Keputusan :

Jika angka Sig. $\geq 0,10$ maka $\mathrm{H}_{0}$ diterima dan Ha ditolak

Jika angka Sig. < 0,10 maka H0 ditolak dan Ha diterima

Hasil uji Sig. $=0,018<0,10$, maka Ho ditolak dan Ha diterima

Kesimpulan :

Dari tabel coefficients, diketahui bahwa variabel kualitas makanan $\left(\mathrm{X}_{1}\right)$ mempunyai nilai Sig sebesar 0,018 jika dibandingkan dengan taraf signifikansi 0,10 maka nilai sig lebih kecil daripada nilai taraf signifikansi $(0,018<0,10)$. Artinya Ho ditolak dan Ha diterima (signifikan) dan besarnya beta (koefisien jalur) variabel kualitas makanan $\left(\mathrm{X}_{1}\right)$ terhadap behavioral intention (Z) adalah 0,351 ( ).

Pengujian secara individual antara kualitas pelayanan $\left(\mathrm{X}_{2}\right)$ dan behavioral intention $(\mathrm{Z})$
Uji t

Hipotesis :

$\mathrm{H}_{0}$ : Tidak ada pengaruh antara kualitas pelayanan terhadap behavioral intention.

$\mathrm{Ha}$ : Ada pengaruh antara kualitas pelayanan terhadap behavioral intention.

Dasar Pengambilan Keputusan :

Jika thitung < ttabel, maka $\mathrm{H}_{0}$ diterima dan $\mathrm{Ha}$ ditolak, jika thitung $\geq$ ttabel, maka $\mathrm{H}_{0}$ ditolak dan Ha diterima

Nilai ttabel dilihat pada taraf signifikansi 0,10 di mana $\mathrm{df}=$ jumlah sampel - jumlah variabel $=100-2=98$. Oleh karena itu, nilai ttabel pada $\mathrm{df}=98$ adalah 1,29. Nilai t-hitung diperoleh pada tabel coefficients, di mana dari tabel coefficients sebelumnya diketahui bahwa besar thitung variabel kualitas pelayanan $\left(\mathrm{X}_{2}\right)$ dan $\mathrm{Z}$ adalah 2,190. artinya thitung $\geq \mathrm{t}$-tabel $(2,190>1,29)$. Dengan demikian, Ho ditolak dan $\mathrm{Ha}$ diterima yang memberikan kesimpulan bahwa variabel kualitas pelayanan $\left(\mathrm{X}_{2}\right)$ berpengaruh secara individu terhadap variabel behavioral intention (Z). 
Uji Signifikansi secara individual

Hipotesis

Ho: kualitas pelayanan tidak berkontribusi secara signifikan terhadap behavioral intention.

Ha: kualitas pelayanan berkontribusi secara signifikan terhadap behavioral intention.

Dasar pengambilan keputusan :

Jika angka Sig. $\geq 0,10$ maka $\mathrm{H}_{0}$ diterima dan Ha ditolak

Jika angka Sig. $<0,10$ maka $\mathrm{H}_{0}$ ditolak dan Ha diterima

Hasil Uji Sig. $=0,037<0,10$, maka Ho ditolak dan Ha diterima

Kesimpulan :

Dari tabel coefficients, diketahui bahwa variabel kualitas pelayanan (X2) mempunyai nilai Sig sebesar 0,037 jika dibandingkan dengan taraf signifikansi 0,10 maka nilai sig lebih kecil daripada nilai taraf signifikansi $(0,037<0,10)$. Artinya Ho ditolak dan $\mathrm{Ha}$ diterima (signifikan) dan besarnya beta (koefisien jalur) variabel kualitas pelayanan $\left(\mathrm{X}_{2}\right)$ terhadap behavioral intention (Y) adalah 0,139.
Pengujian secara individual antara kepuasan pelanggan (Y) dan behavioral intention $(\mathrm{Z})$

Uji t

Hipotesis :

$\mathrm{H}_{0}$ : Tidak ada pengaruh antara kepuasan pelanggan terhadap behavioral intention.

Ha: ada pengaruh antara kepuasan pelanggan terhadap behavioral intention.

Dasar Pengambilan Keputusan :

Jika thitung < t-tabel, maka $\mathrm{H}_{0}$ diterima dan Ha ditolak, jika thitung $\geq$ ttabel, maka $\mathrm{H}_{0}$ ditolak dan $\mathrm{Ha}$ diterima

Nilai t-tabel dilihat pada taraf signifikansi 0,10 di mana $\mathrm{df}=$ jumlah sampel- jumlah variabel $=100-2=98$. Oleh karena itu, nilai t-tabel pada $\mathrm{df}=$ 98 adalah 1,29. Nilai thitung diperoleh pada tabel coefficients, di mana dari tabel coefficients sebelumnya diketahui bahwa besar thitung variabel kepuasan pelanggan (Y) dan $\mathrm{Z}$ adalah 7.469. artinya thitung $\geq$ ttabel $(7.469>1,29)$. Dengan demikian, Ho ditolak dan $\mathrm{Ha}$ diterima yang memberikan kesimpulan bahwa variabel kepuasan pelanggan (Y) berpengaruh secara individu terhadap variabel Z. 
Uji Signifikansi secara individual

Hipotesis

Ho: kepuasan pelanggan tidak berkontribusi secara signifikan terhadap behavioral intention.

Ha: kepuasan pelanggan berkontribusi secara signifikan terhadap behavioral intention.

Dasar Pengambilan Keputusan :

Jika angka Sig. $\geq 0,10$ maka $\mathrm{H} 0$ diterima dan Ha ditolak, jika angka Sig. $<0,10$ maka $\mathrm{H}_{0}$ ditolak dan Ha diterima Hasil :
Uji Sig. $=0,000<0,10$, maka Ho ditolak dan Ha diterima

Kesimpulan :

Dari tabel coefficients, diketahui bahwa variabel kepuasan pelanggan (Y) mempunyai nilai Sig sebesar 0,000 jika dibandingkan dengan taraf signifikansi 0,10 maka nilai sig lebih kecil daripada nilai taraf signifikansi $(0,000<0,10)$. Artinya Ho ditolak dan $\mathrm{Ha}$ diterima (signifikan) dan besarnya beta (koefisien jalur) variabel kepuasan pelanggan (Y) terhadap behavioral intention $(\mathrm{Z})$ adalah $\quad 0,698$.

Tabel 9 Hasil Rangkuman Pengujian Sub-Struktur 2

\begin{tabular}{|c|c|c|c|c|c|}
\hline $\begin{array}{c}\text { Pengaruh } \\
\text { Antar } \\
\text { Variabel }\end{array}$ & $\begin{array}{c}\text { Koefisien } \\
\text { Jalur } \\
\text { (Beta) }\end{array}$ & Sig. & $\begin{array}{l}\text { Pengujian } \\
\text { Hipotesis }\end{array}$ & $\begin{array}{c}\text { Koefisien } \\
\text { Determinasi }\end{array}$ & $\begin{array}{c}\text { Koefisien } \\
\text { Variabel } \\
\text { Lain } \\
(\rho z \varepsilon 2)\end{array}$ \\
\hline X1 terhadap Z & 0,351 & 0,018 & $\mathrm{H}_{\mathrm{a}}$ Diterima & & \\
\hline $\mathrm{X} 2$ terhadap $\mathrm{Z}$ & 0,139 & 0,037 & $\mathrm{H}_{\mathrm{a}}$ Diterima & $0,767(76,7 \%)$ & 0,482 \\
\hline Y terhadap Z & 0,698 & 0,000 & $\mathrm{H}_{\mathrm{a}}$ Diterima & & \\
\hline
\end{tabular}

Berdasarkan hasil rangkuman tersebut, maka dengan digambarkan diagram jalur sub-struktur 2 dengan ditampilkan nilai koefisien regresi antara lain: 
Ganbar 4 Sub-struktur 2 beserta koefisien jalur

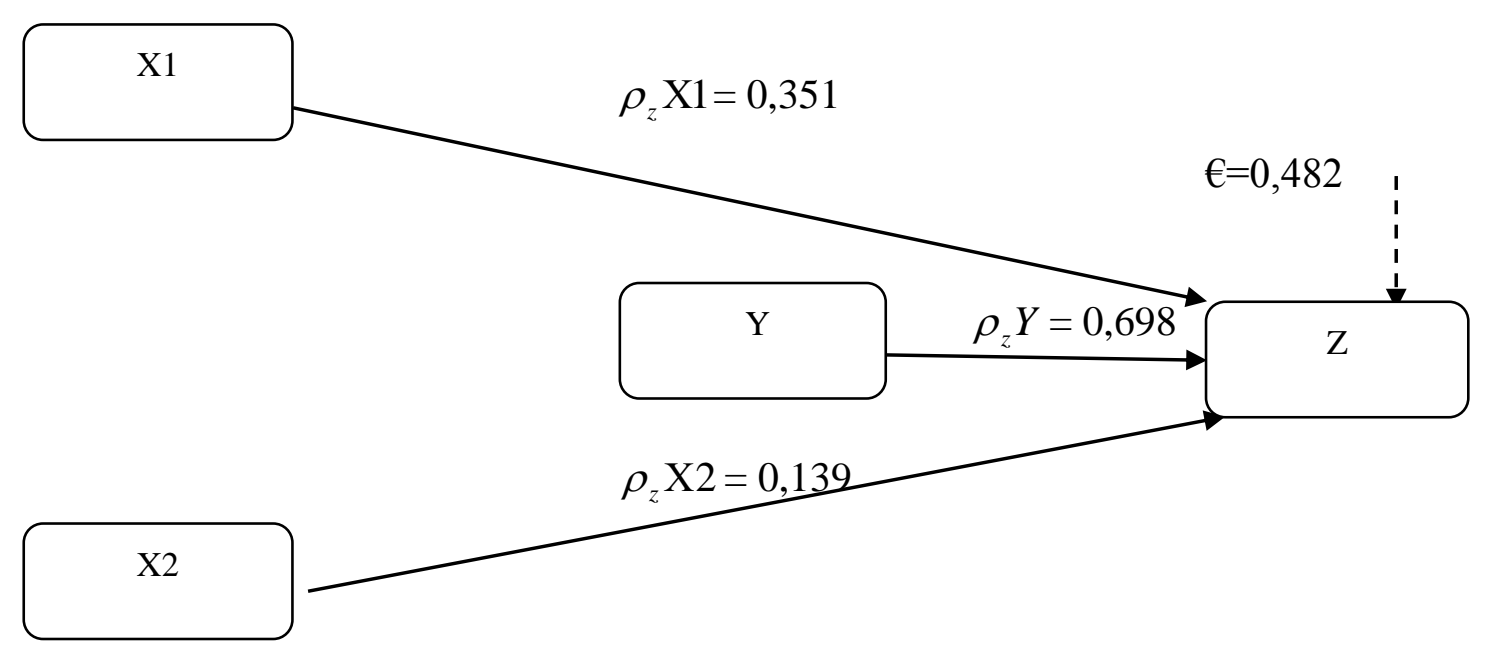

Diperoleh persamaan sub-struktur 1 :

$Z=\rho_{z X} 1+\rho_{z X} 2+\rho_{Y} \varepsilon_{1}$

$Z=0,351 X 1+0,139 X 2+0,482 \varepsilon_{1} \quad$ di mana $\mathrm{R}^{2}=0,767$

Berikut ini dirangkum keseluruhan koefisien jalur dari hubungan kausal yang dapat diketahui pengaruh langsung dan tidak langsung, serta pengaruh total dari kualitas makanan $\left(\mathrm{X}_{1}\right)$ dan kualitas pelayanan $\left(\mathrm{X}_{2}\right)$ terhadap kepuasan pelanggan (Y) dan dampaknya pada behavioral intention $(\mathrm{Z})$ koefisien jalur $\mathrm{X}_{1}$ terhadap $\mathrm{Y}$ adalah 0,389 , koefisien jalur $\mathrm{X}_{2}$ terhadap $\mathrm{Y}$ adalah 0,027 , koefisien jalur $\mathrm{X}_{1}$ terhadap $\mathrm{Z}$ adalah 0,351, koefisien jalur $\mathrm{X}_{2}$ terhadap $\mathrm{Z}$ adalah 0,139 , koefisien jalur $Y$ terhadap $\mathrm{Z}$ adalah 0,698 Untuk lebih jelasnya, tabel berikut merangkum seluruh hasil koefisien jalur beserta pengaruh tidak langsung dan pengaruh total sebagai berikut: 
Tabel 10. Hasil Rangkuman Pengujian Analisis Path Keseluruhan

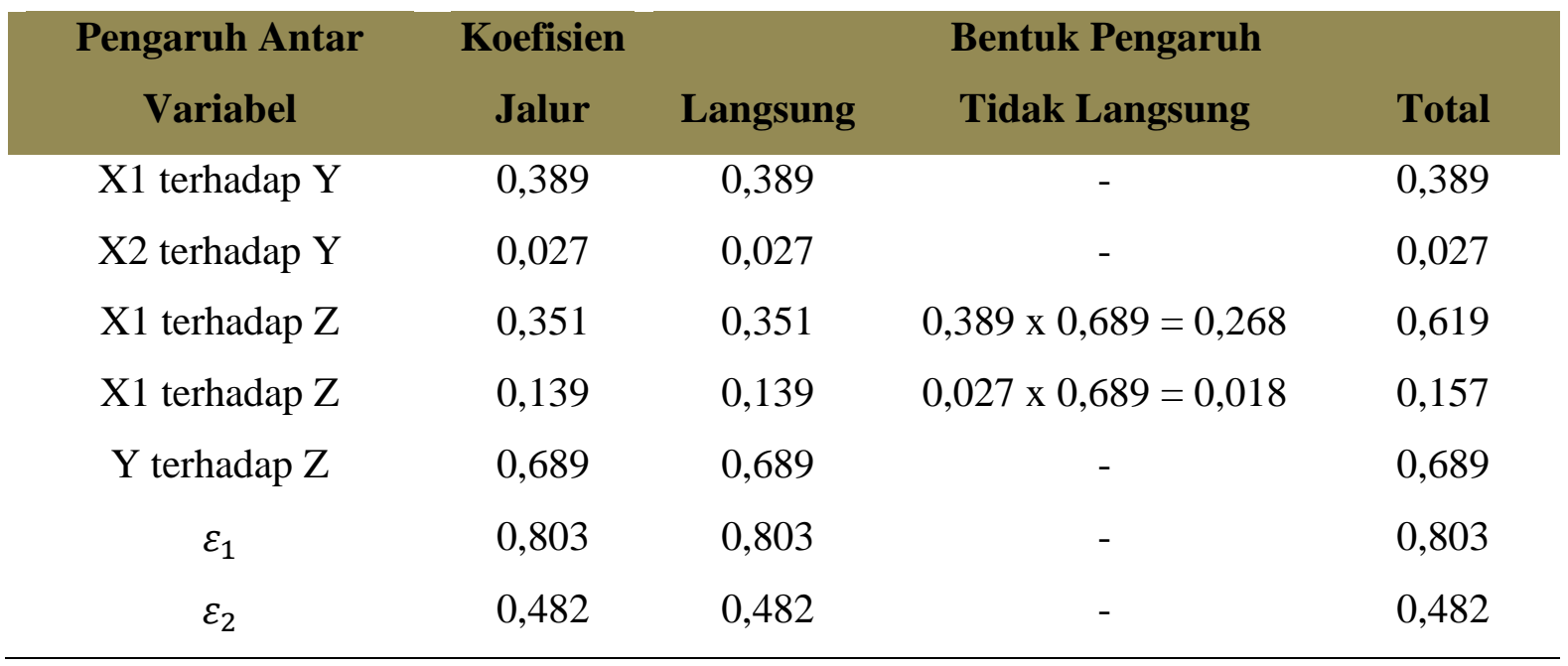

Gambar 5. Hasil Keseluruhan Model Struktur Path Analysis

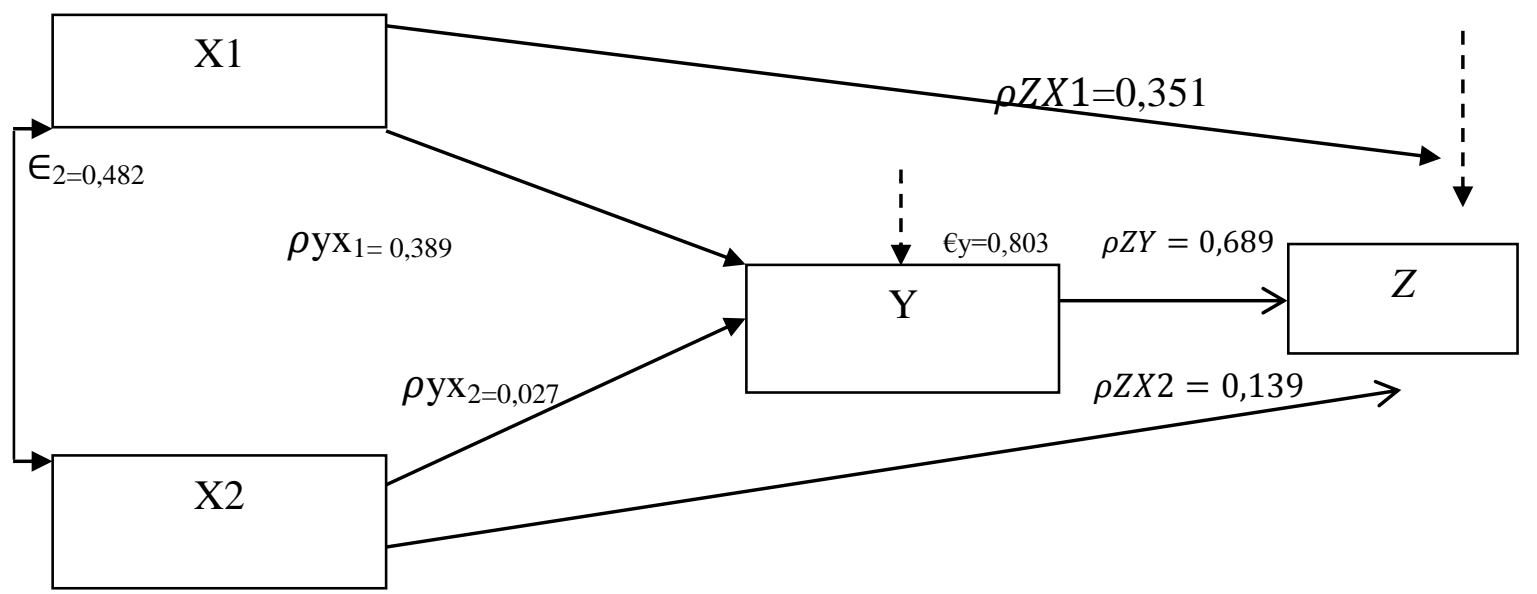

\section{SIMPULAN DAN SARAN}

Berdasarkan hasil keseluruhan dalam penelitian ini berikut ini dapat diketahui beberapa implikasi dalam penelitian ini antara lain:

1. Kualitas makanan terbukti secara signifikan dapat memengaruhi kepuasan pelanggan. Jadi saat kualitas makanan semakin meningkat, maka kepuasan pelanggan juga akan meningkat. Begitu juga sebaliknya, jika kualitas makanan menurun, maka kepuasan pelanggan juga akan menurun. Maka dari itu restoran Top Yammie seharusnya perlu meningkatkan kualitas makanan yang disajikan dalam rangka meningkatkan kepuasan 
pelanggan. Restoran Top

Yammie dapat meningkatkan tingkat kepuasan pelanggan dengan cara mengevaluasi faktor-faktor yang membentuk kualitas makanan. Kualitas makanan memiliki hubungan dengan kepuasan pelanggan dengan sifat pengaruh "cukup kuat" sebesar 54,6\% dan sisa nya $45,4 \%$ di pengaruhi variabel lain yang tidak di bahas pada penelitian ini. Selanjutnya, dengan menghitung rata-rata terendah dari hasil kuesioner responden mengenai kualitas makanan restoran Top Yammie ditemukan rata-rata terendahnya adalah pernyataan nomor 4 dengan isi pernyataan "Makanan yang disajikan oleh restoran Top Yammie mempunyai cita rasa yang enak "sebesar 3.12

2. Kualitas pelayanan terbukti secara signifikan dapat memengaruhi kepuasan pelanggan. Jadi saat kualitas pelayanan semakin meningkat, maka kepuasan pelanggan juga akan meningkat. Begitu juga sebaliknya, jika kualitas pelayanan menurun, maka kepuasan pelanggan juga akan menurun. Maka dari itu restoran Top Yammie seharusnya perlu meningkatkan kualitas pelayanan yang diberikan dalam rangka meningkatkan kepuasan pelanggan. Kualitas pelayanan memiliki hubungan dengan kepuasan pelanggan dengan sifat pengaruh "rendah" sebesar $35,4 \%$ dan sisa nya $64,6 \%$ di pengaruhi variabel lain yang tidak di bahas pada penelitian ini. Selanjutnya, dengan menghitung rata-rata terendah dari hasil kuesioner responden mengenai kualitas pelayanan restoran Top Yammie ditemukan rata-rata terendahnya adalah pernyataan nomor 4 dengan isi pernyataan "Pelayan memiliki pengetahuan mengenai makanan-makanan yang ada di menu," sebesar 3.14

3. Kepuasan pelanggan juga terbukti secara signifikan memengaruhi behavioral intention. Jadi setiap kali tingkat kepuasan pelanggan menurun, maka tingkat behavioral intention juga akan menurun. 
Sebaliknya, jika tingkat kepuasan pelanggan meningkat, maka behavioral intention juga akan meningkat. Jadi untuk meningkatkan behavioral intention pada konsumen, makan restoran Top Yammie dapat memperbaikinya dengan cara meningkatkan kepuasan pelanggan. Kepuasan pelanggan memiliki hubungan dengan behavioral intention dengan sifat pengaruh "kuat" sebesar $77,6 \%$ dan sisa nya $22,4 \%$ di

\section{DAFTAR PUSTAKA}

Al-Tit (2015) The Effect of Service and Food Quality on Customer Satisfaction and Hence Customer Retention . Asian Social Science; Vol. 11, No. 23.

Aliman dan Mohamad (2013).

Perceptions of Service Quality and Behavioral Intentions: A Mediation Effect of Patient

Satisfaction in the Private Health Care in Malaysia.International Journal of Marketing Studies, Vol. 5, No. 4.

American Marketing Association (2013) Definition Of Marketing. https://www.ama.org/AboutAM A/Pages/Definition-ofMarketing.aspx. [10 Juni 2017]

Anwar, A.P. (2012). Psikologi

Pelayanan. Bandung: Alfabeta. pengaruhi variabel lain yang tidak di bahas pada penelitian ini. Selanjutnya, dengan menghitung rata-rata terendah dari hasil kuesioner responden mengenai kualitas pelayanan restoran Top Yammie ditemukan rata-rata terendahnya adalah pernyataan nomor 3 dengan isi pernyataan "Saya sangat menikmati makanan dari restoran Top Yammie" memiliki nilai rata-rata terendah sebesar 3.38

Buchari Alma (2011). Manajemen Pemasaran dan Pemasaran Jasa. Bandung : Penerbit Alfabeta.

Canny (2014). Measuring the Mediating Role of Dining Experience Attributes on Customer Satisfaction and Its Impact on Behavioral Intentions of Casual Dining Restaurant in Jakarta. International Journal of Innovation, Management and Technology, Vol. 5, No. 1

Daryanto (2013). Strategi dan Tahapan Mengajar. Bandung: CV Yrama Widya.

Fornell, C. (1992) A National Customer Satisfaction Barometer: The Swedish Experience. Journal of Marketing, Vol. 56.

Hasan, A. (2014). Marketing dan Kasus-Kasus Pilihan. CAPS. Yogyakarta. 
Ha'ghighi et al (2012). Evaluation of factors affecting customer loyalty in the restaurant industry. African Journal of Business Management, Vol. 6 No.14.

Haery dan Badiezadeh (2014). Studying the Effect of Food Quality Dimensions (Physical Environment, Food and Services) on Mental Image of the Restaurant and Customers' Satisfaction and Intentions based on Kisang's Model. International Journal of Academic Research in Business and Social Sciences Vol. 4 No.7.

Giese dan Cote. (2000). Defining Consumer Satisfaction. Academy of Marketing Science Review, Vol 2 No. 1

Griffin, J. (2005). Customer Loyalty, Menumbuhkan dan Mempertahankan Kesetiaan Pelanggan. Jakarta : Erlangga.

Goetsh dan Davis (2002). Pengantar Manajemen Mutu 2 Edisi Bahasa Indonesia, Jakarta: PT Prenhalindo.

Gronroos, C. (1990). Service Management and Marketing: Managing the Moment of Truth in Service Competition. Massachusetts: Lexington.

Kotler dan Armstrong (2012). PrinsipPrinsip Pemasaran. Edisi 13 Jilid 1. Jakarta: Erlangga.

Kotler dan Keller (2009). Manajemen Pemasaran. Jilid 1. Edisi 13 Jakarta: Erlangga.
Kotler dan Keller (2012). Marketing Management. New Jersey: Person Prentice Hall.

Lovelock, C dan Wirtz (2011). Service Marketing. New Jersey USA: Pearson.

Mahmoeddin. H (2010). Melacak Kredit Bermasalah. Jakarta : Pustaka Sinar Harapan.

Mauludin, H.(2010). Metode Penelitian Dan Pengolahan Data Penelitian (pendekatan praktis). Singosari.

Mursid. M (2012). Manajemen Pemasaran, PT Bumi Aksara. Jakarta.

Parasuraman, A. (2001). The Behaviorial Consequenses of Service Quality. Jurnal of Marketing, Vol 60.

Potter, N and Hotchkiss. H (2012) Food Science 5th Edition. New York : Chapman \& Hall.

Rozekhi et al (2016) The Influence of Food Quality on Customer Satisfaction in Fine Dining Restaurant: Case in Penang. International Academic Research Journal of Business and Technology, Vol.2 No.2.

Sangadji, E.M., dan Sopiah (2013).

$\begin{array}{lr}\text { Perilaku } & \text { Konsumen: } \\ \text { Pendekatan } & \text { Praktis } \\ \text { Disertai:Himpunan } & \text { Jurnal } \\ \text { Penelitian. Yogyakarta: Penerbit } & \text { Andi. }\end{array}$


Schiffman, L dan Kanuk L. (2010).

Consumer Behavior. Fifth

Edition. Prentice-Hall Inc. New Jersey

Shaharudin et al (2011). Food Quality Attributes among Malaysia's Fast Food Customer. Journal International Business and Management, Vol. 2, No. 1.

Stanton (2003). Prinsip Pemasaran. Alih Bahasa oleh Sadu Sundaru. Jilid Satu. Edisi Kesepuluh. Jakarta:Erlangga.

Suwithi et al (2008). Akomodasi

Perhotelan 2. Jakarta: Direktorat Pembinaan Sekolah Menengah Kejuruan, Direktorat Jenderal Manajemen Pendidikan Dasar Dan Menengah, Departemen Pendidikan Nasional.

Sumarwan, et al. (2011). Riset

Pemasaran dan Konsumen: Panduan Riset dan Kajian Kepuasan, Perilaku, Pembelian, Gaya Hidup, Loyalitas dan Persepsi Risiko. IPB Press. Bogor.

Sunyoto, D ( 2013). Perilaku

Konsumen, CAPS (Center of Academy Publishing Service), Yogyakarta.
Takahashi et al. (2011). Effect of Silicon on the Growth of Rice Plant at Different Growth Stages. Soil Science Plant Nutrition, 35: 347-356.

Tjiptono, F. (2012) Pemasaran Jasa. Yogyakarta: CV ANDI OFFSET.

Tjiptono, dan Chandra. (2011). Service, Quality and Satisfaction. 3rd. Yogyakarta. Andi.

Widiyono dan Pakkanna (2013). Pengantar Bisnis Respon terhadap Dinamika Global, Edisi Pertama, Motra Wacana Media, Jakarta.

Woo Joung et al (2015). The Impact of Perceived Service and Food Quality on Behavioral Intentions in Continuing Care Retirement Communities: A Mediating Effect of Satisfaction. Journal of Quality Assurance in Hospitality \& Tourism, Vol.16, No.6. 